\title{
Exploring the Factors Influencing Employees' Willingness to Use Mobile Applications in Oman: Using UTAUT Model
}

\author{
Laila Al-Azizi ${ }^{1}$, Ali H. Al-Badi ${ }^{2}$ and Taiba Al-Zrafi ${ }^{3}$ \\ ${ }^{1,2}$ Department of Information Systems, College of Economics and Political Science, Sultan Qaboos \\ University, Al-Khodh, Muscat, Oman \\ ${ }^{3}$ Civil Service Employees Pension Fund, Muscat, Oman
}

Correspondence should be addressed to: Ali H. Al-Badi; aalbadi@squ.edu.om

Received date: 6 February 2017; Accepted date: 23 January 2018; published date: 15 February 2018

Academic Editor: Mohammad Mansour Fawwaz Al-Khasawneh

Copyright (@ 2018. Laila Al-Azizi, Ali H. Al-Badi and Taiba Al-Zrafi. Distributed under Creative Commons CC-BY 4.0

\begin{abstract}
Nowadays, people are on the move and they are using mobile applications on mobile phones, tablets, or other mobile devices. That is why mobile applications are becoming so much important in our daily-life. Mobile applications allow customers to have services readily available. Obviously, mobile technology is significantly expanding governments' capacity to extend access to existing services, to expand the delivery of new services, to increase active citizen participation in government operations and to change the way of working within the public sector. Most government departments/agencies are facing some challenges and barriers adopting mobile applications. The factors that influence the employees' acceptance and willingness to use these applications in their daily work are crucial; therefore, exploring such factors is of significant importance. This study aims to investigate Omani government employees' willingness to adopt and use mobile applications. In addition, it aims to explore the extent to which the employees believe that mobile applications' adoption contributes in improving productivity and work efficiency. The investigation employs a research model, which is based on Unified Theory of Acceptance and Use of Technology (UTAUT). To achieve research objectives a quantitative approach was adopted, in which questionnaire was utilized to collect the required data. It was found that the performance expectancy, effort expectancy and facilitating conditions (independent variables) have positive influence on the behavioral intention of the government employees to use the mobile applications, and the moderators (age, gender, experience and awareness) have a moderating impact on the relationship between the independent factors and behavioral intention to use the mobile applications.
\end{abstract}

Keywords: Mobile application, E-services, E-government

Cite this Article as: Laila Al-Azizi, Ali H. Al-Badi and Taiba Al-Zrafi (2018)," Exploring the Factors Influencing Employees' Willingness to Use Mobile Applications in Oman: Using UTAUT Model ", Journal of e-Government Studies and Best Practices, Vol. 2018 (2018), Article ID 553293, DOI:10.5171/2018. 553293 


\section{Introduction}

Mobile applications, or mobile apps, are a type of software application that are designed to be used on mobile devices such as smartphones and tablets. Nowadays, mobile applications have been widely used in all fields. The reasons of this is that mobile devices are small size, portable and through the Internet would facilitate the access to information at any place and any time [Biel et al., 2010].

The technology development improved the mobile phones power, connectivity, communication proficiency, flexibility, accessibility and usability. On the other hand, the telecommunication sector development and the initiation of third generation (3G) and forth generation (4G) networks have significantly upgraded mobile bandwidth, empowering the delivering of content and services[Biel et al., 2010]. All these factors contribute to encouraging the organizations to offer their services through an adoption of mobile applications [Payne, 2013].

The integration between mobile devices and business applications opens a new and effective communication channel between the organization staff and the citizens. It also allows the agencies to transform the traditional services into electronic services. For example, in Africa the rate of using mobile phones raised from $50 \%$ to $58.4 \%$ in 2013 , since they introduced a new mobile application that facilitates online payment transactions and allows the customers to apply for products and services through this application [Murugesan, 2013]. Moreover, European transportation companies offer services through mobile application that allow the customers to book their train tickets and pay their electricity bills just by one click from their mobile devices [Aljawarneh et al., 2012].

This study examines some important factors that may affect employees' behavioral intention to use mobile applications in their daily work. Several factors were taken into account in this study such as agencies' readiness, mobile application ease of use, employees' behavior towards and their trusts on mobile application to enhance their work performance.

This study will focus on the following key research questions:

- What are the factors that would affect employees' behavioral intention in using mobile applications?

- Do the government employees have the convictions to apply the mobile application in their daily business?

The following sections of the paper are organized as follows: section two provides literature reviews on the evolution of mobile application and the employed hypotheses using UTAUT model, section three outlines the adopted research methodology, section four presents the data analysis, section five presents a discussion around the findings, and section six presents research limitation and future recommendations and finally the conclusion.

\section{Literature Review}

\section{E-government is the main initiation of e- services}

E-government is viewed as the use of electronic systems such as Internet websites to improve the access to and distribution of government information and services to the citizens, business stakeholders, employees, other organizations and government agencies. It acts as a digital collaboration between the entities in the government sector and citizens and also within the entities themselves. The aim of e-government is to deliver faster, cheaper, quality services and information to the public, internal staff and other entities within government boundary [Lofstedt, 2012].

Governments worldwide are directed to adopt and innovate in the methods of 
delivering their information as well as enhancing how to present their services to the citizens [Norris and Reddick, 2013]. This phenomenon focuses on the adoption of a mixture of e-services and communication technologies as well as the migration from the traditional services to the online services. It deals with 3 segments such as "Government to Citizen(G2C), Government to Business (G2B) and Government to Government (G2G)" [Li and Feeney, 2014].

As an illustration, Alshehri et al. [2013] clarify in their study that most of the services which are provided by the government entities are considered within (G2C). This type utilizes electronic resources according to the individuals' daily transactions. It enables the communication and interaction between the government and citizens by implementing e-government to support the improvement of public services. It also applies the convenient information access to the citizens such as the capability to apply certificates and fees payment through government agencies portals. This concept of G2C benefits the citizens because it contributes to reducing services procedures time and overcoming some of the geographic issues that citizens face in manual process [Alshehri et al., 2013].

Many studies concentrate on the original model E-government where Siddique and Khan [2015] stated that E-government is the initiation of transformation for most types of the business to e-services in public sector. It seeks to improve public service capability; transparency and offer the information and services digitally in 24 hours per 7 days [Siddique and Khan, 2015].

E-government adoption depends on successful adopting of several instruments such as ICT technologies, readiness of the Internet infrastructure and telecommunication network [Al Hujran et al., 2013]. For example, Al Hujran et al. [2013] stated that Jordan has improved their national portal and e-government websites by offering additional functions such as SMS gateway which allow public users to communicate and interact effectively with the government. This communication contributes to innovating and enhancing in the services deliverable to the citizens [Al Hujran et al., 2013].

Alshehri et al. [2012a] reported that many countries are in the process of transformation to e-government for example, in the Middle East Kingdom of Saudi Arabia (KSA), most of its 22 government agencies have their own websites and just 8 from these agencies which did not implement some of the main functions in their websites, around 45.4 percent of the services were completely implemented in 10 agencies' portals and 13.6 percent were in the final stage of adoption while 6 agencies still did not implement any online services [Alshehri et al., 2012a].

Al-Busaidy and Weerakkody [2009] emphasize that the project initiation of egovernment in Oman was in 2003 and official e-government efforts in Oman were established (referred to as "e-Oman") which are responsible for administrating the egovernment and e-commerce process. This organization is also responsible for facilitating the needed technologies such as infrastructure, web portal and information for the government agencies to join in egovernment projects [Al-Busaidy and Weerakkody, 2009]. Ministerial Cabinet approved the strategy of e-government transformation in 12th of Jun 2012. The objectives of this strategy were distributed to the government agencies in order to be included in their internal strategies.

It aims to improve the integration of services' quality and to be provided to the citizens in the form of electronic services (e-services) [e-Oman, 2016]. E-government processes are built to be implemented in four stages:

- Information: covers the government agencies information to be published in their website for citizens to make it easier for them to track the 
procedures about their requested services

- Interaction: allows citizens to interact and download services' applications instead of getting them as a hardcopy from the agency

- Transaction: provides digital documents that are offered in the government agencies' websites.

- Transformation: involves e-service delivery to the citizens because the procedures within agencies departments will be completed electronically from the begging of a service request [ITA, 2016].

In 2014, the UN world e-government readiness survey exposed that the Omani egovernment efforts improved significantly since the 2005 survey by moving up from 84 to 44 in the rankings within the Gulf Cooperation Council (GCC) countries [United Nations, 2014].

\section{Collaboration of E-government and M- Government}

Mobile government (M-government) is considered as practical division of all comprehensive e-government that utilizes the combination features of mobile and wireless technologies such as smart phone devices, laptops and personal digital assistance devices [Sareen and Chanana, 2013]. Sultana and Ahlan [2014] define mgovernment as services or information delivered to the citizens through mobile devices and wireless communication technologies such as WAN, Wifi, WiMax, etc. under the supervision of government [Sultana and Ahlan, 2014]. Kushchu and Kuscu [2003] define m-government as a strategy that aims to improve government's outcome, meets citizens, business and government units aspects and positively impact the economic growth by utilizing different types of wireless technology, mobile devices, services and software applications [Kushchu and Kuscu, 2003].
In fact most of the researchers studied if egovernment will be replaced by mgovernment, Kushchu and Kuscu [2003] argued that e-government cannot be replaced by m-government instead it is an accumulative effort of e-government. Egovernment delivers the services through wired networks and with support of intelligent systems such as web applications while m-government aims to provide a mobility of services to the citizens and enhance internal operations of the government agencies using wireless applications through mobile devices. Mgovernment facilitates providing real time information and presents the government's services to citizens in more easiest methods [Kushchu and Kuscu, 2003].

M-government is a significant contribution for the government agencies to be more proactive in their processes and services because it allows citizens to participate directly in the government's operations. It contributes to developing the existing services and creating interactive citizens that are able to communicate with agencies at anytime and anywhere [Sareen and Chanana, 2013]. It focuses on some typical improvements in the government sector such as:

- The government agencies strategic utilization of mobile technologies,

- Transforming the methods of government work to more effective mobility working,

- Structuring the work of government institutions and enhancing the employees productivity,

- $\quad$ Offering the best flexible services delivery to the citizens to meet their perspectives [TRA, 2013],

- Zukang et al. [2011] illustrate in their book that there are four deployment models for M-government, the table 1 below explains with examples for each model and the type of service delivery [Zukang et al., 2011]. 
Table 1: Deployment of the mobile services' four models

\begin{tabular}{|c|c|c|c|}
\hline Model & Target & Type of services & Example \\
\hline $\begin{array}{l}\text { M-government } \\
\text { to citizen } \\
\text { (MG2C) } \\
\text { [Zukang et al., } \\
\text { 2011] }\end{array}$ & $\begin{array}{l}\text { Individual: } \\
\text { Create an effective interaction } \\
\text { between government and citizens } \\
\text { that allow citizen response and } \\
\text { communication are } \\
\text { preferable[Zukang et al., 2011]. }\end{array}$ & $\begin{array}{l}\text { Push services: } \\
\text { informational and } \\
\text { educational services } \\
\text { - One to one: interactive } \\
\text { services } \\
\text { Two way transactions: } \\
\text { transactional services } \\
\text { - Engage both government } \\
\text { and citizens [Zukang et } \\
\text { al., 2011] }\end{array}$ & $\begin{array}{lr}\text { Broadcast bulk SMS, } \\
\text { access forms, information } \\
\text { inquiries, service request, } \\
\text { completer transactions, } \\
\text { submit claims and } \\
\text { comments, report } \\
\text { problems, request } \\
\text { emergency assistance and } \\
\text { access data, events } \\
\text { notification, job posting, } \\
\text { service } \\
\text { participation in voting } \\
\text { [Zukang et al., 2011] }\end{array}$ \\
\hline $\begin{array}{l}\text { M-government } \\
\text { to government } \\
\text { (MG2G)[Zukang } \\
\text { et al., 2011] }\end{array}$ & $\begin{array}{l}\text { Agencies: } \\
\text { Act as a back office, the agencies } \\
\text { transform themselves to be } \\
\text { connected with citizens and } \\
\text { respond to their needs [Zukang et } \\
\text { al., 2011] }\end{array}$ & $\begin{array}{l}\text { Exchanging information } \\
\text { between the government } \\
\text { agencies as an integrated } \\
\text { services [Zukang et al., 2011] }\end{array}$ & $\begin{array}{lr}\text { Patient records } & \text { across all } \\
\text { government } & \text { hospitals } \\
\text { [TRA, 2013] } & \end{array}$ \\
\hline $\begin{array}{l}\text { M-government } \\
\text { to Business } \\
\text { (MG2B) } \\
\text { [Zukang et al., } \\
\text { 2011] }\end{array}$ & $\begin{array}{l}\text { Agencies: } \\
\text { Describe the interaction between } \\
\text { government agencies and business' } \\
\text { stakeholders [Zukang et al., 2011] }\end{array}$ & $\begin{array}{l}\text { Sharing information related } \\
\text { to business between } \\
\text { government agencies such as } \\
\text { polices regulations and } \\
\text { access to applications } \\
\text { [Zukang et al., 2011] }\end{array}$ & $\begin{array}{l}\text { Procurement process, } \\
\text { support access to kiosks } \\
\text { and low-cost handsets } \\
\text { licenses renewal such as } \\
\text { in Ministry of } \\
\text { manpower[TRA, 2013] }\end{array}$ \\
\hline $\begin{array}{l}\text { M-government } \\
\text { to Employee } \\
\text { (MG2E) } \\
\text { [Rashid, 2014] }\end{array}$ & $\begin{array}{l}\text { Individual: } \\
\text { Act as a back office that support the } \\
\text { interaction between government } \\
\text { agencies and their employees } \\
\text { [Zukang et al., 2011] }\end{array}$ & $\begin{array}{l}\text { Facilitate ICT tools to enable } \\
\text { training and maximize the } \\
\text { resources to improve } \\
\text { agencies efficiency and } \\
\text { accountability [Zukang et al., } \\
\text { 2011] }\end{array}$ & $\begin{array}{l}\text { Support remote access to } \\
\text { employees who are in } \\
\text { remote locations [Zukang } \\
\text { et al., 2011] }\end{array}$ \\
\hline
\end{tabular}

\section{M-Government adding value to citizens and government agencies}

The evolution of communication networks and mobile devices is considered as an advancement and powerful enabler of $\mathrm{M}$ government. This evolution could be considered as strength point that structures the usage of technology and acts as an important built on foundation for all Mgovernment services.

In the context of M-government, people will need to touch the benefits of performing the government transactions through mobile devices [Abdelghaffar and Magdy, 2012]. For example, the UK introduced an electronic voting, which enables citizens to vote via mobile devices as a convenient method to involve citizens in political decision making [Kailasam, 2010].

There are several benefits provided for citizens compared to traditional methods of delivering information and services. Some of these advantages are: 
- Smartphone and comparable mobile devices are usually carried and always on. Hence, these devices provide users the capability to communicate everywhere and anytime. In the context of M-government, this means that citizens are able to continuously access M-government services independently of the current time and their current location. Government based solutions usually require citizens to sit in front of a PC and hence bind them to fixed locations. Compared to paper based administrative procedures in offices of public administrations, M-government services have the benefits to be accessible independently from office hours [Zukang et al., 2011].

- Characteristic of mobile phones makes not only M-government Services, but also citizens accessible anytime. Mobile phones can therefore be used to speed up the information flow between different parties involved in administrative procedures. For example, mobile communication networks can be used to broadcast urgent informational messages from the government to the people [Murugesan, 2013].

- The simplicity of using mobile communication technologies can improve several processes in terms of efficiency. This way, the usage of mobile technologies in governmental and administrative processes can help to save time and money [Murugesan, 2013].

- Mobile phones are usually very personal devices. While for instance computers are often shared within a family, mobile phones usually belong to one person only. Hence, when used within Mgovernment, these devices provide more personalization opportunities for targeting users [Zukang et al., 2011].

- Smart phones and similar devices support different forms of interaction. For instance, many mobile phones may be alternatively controlled via voice. Likewise, Mobil communication itself can be based either on voice or alternatively on text messaging. These choices between different types of interaction and communication can assist disabled people to access administrative and governmental services [Zukang et al., 2011].

- In several developing regions, mobile penetration exceeds Internet penetration. Hence, mobile phones are the only available means for people to get in contact with administrative agencies and bodies electronically. In these areas, missing infrastructures often inhibit the application of classical E-government services. In contrast, Mgovernment solutions based on available $3 \mathrm{G}$ and $4 \mathrm{G}$ mobile networks are feasible and an easy method for governments to get in contact with their citizens [Murugesan, 2013].

Therefore m-government is a solution to the digital divide and can even strengthen democracy. Al-Shihi et al. [2009] claim that "in the long run, indicative of an effective mgovernment is the proactive participation of citizens in decision making, policy formulation and towards the end, nation building".

Previous studies indicated that mgovernment would facilitate the organization's services too; the following points are some advantages that benefit and improve the agencies' businesses [Siddique and Khan, 2015; McLandress, 2013]:

- Structures the agencies business, which will assist in cutting cost without reducing services

- Takes advantages of the power of technology such as social media, mobile apps to provide more verities of communications and access channels with citizens [Zukang et al., 2011]

- Seeking "citizens' social and economic needs" [Zukang et al., 2011]

- Increases attention by developing mobile applications and allows easy access to services or products according to the customer's potential [Siddique and Khan, 2015] 
- Enhances commitment because the enterprises offer their services and products online to raise the productivity and progress of their internal procedures [Siddique and Khan, 2015]

- Reduces cost, efforts and time for the agencies since some of the services would be provided through the mobile government [McLandress, 2013]

On the other hand, it is predicted that this technology would still have some limitations. For instance the following are some potential limitations:

- Connectivity might be slow and unreliable
- Mobile devices limitations, i.e. small screen size, resolution of mobile devices

- Limited processing capability and power, data entry method differs from PC

- Un-readiness of the users to shift to the technology

- Failure in marketing of the services

- Lack of required infrastructure [Siddique and Khan, 2015].

\section{Transition of M-government}

For the purpose of understanding the needs to adopt M-government, it is necessary to understand the difference between $\mathrm{e}$ government and M-government. Table 2 below compares and contrasts the features of electronic and mobile government:

Table 2: Comparison between features of electronic and mobile government

\begin{tabular}{|c|c|c|c|c|c|c|c|}
\hline & $\begin{array}{l}\text { Type of } \\
\text { devices }\end{array}$ & Personalization & $\begin{array}{c}\text { Services } \\
\text { Availability }\end{array}$ & Mobility & $\begin{array}{c}\text { Accessibilit } \\
\mathbf{y}\end{array}$ & $\begin{array}{c}\text { Limitatio } \\
\mathbf{n}\end{array}$ & $\begin{array}{c}\text { Services } \\
\text { bounda } \\
\text { ries }\end{array}$ \\
\hline $\begin{array}{l}\text { E- } \\
\text { governme } \\
\text { nt }\end{array}$ & $\begin{array}{l}\text { Desktop } \\
\text { computer } \\
\text { s, } \\
\text { Laptops, } \\
\text { land } \\
\text { telephone } \\
\text { devices }\end{array}$ & $\begin{array}{l}\text { The devices can } \\
\text { be accessed by } \\
\text { multiple users, it's } \\
\text { not personalized } \\
\text { according to the } \\
\text { individual } \\
\text { preferences which } \\
\text { is fixed and not } \\
\text { allow to send } \\
\text { personal } \\
\text { information to } \\
\text { division } \\
\text { devices[Hassan et } \\
\text { al., 2009] }\end{array}$ & $\begin{array}{l}\text { The services are } \\
\text { not available all } \\
\text { the time because } \\
\text { it depend on the } \\
\text { status of the } \\
\text { devices if it } \\
\text { switched off or } \\
\text { on[Lofstedt, } \\
\text { 2012] }\end{array}$ & $\begin{array}{l}\text { The devices } \\
\text { are not } \\
\text { portable, it } \\
\text { is located in } \\
\text { fixed place } \\
\text { so the } \\
\text { individual } \\
\text { should } \\
\text { search for } \\
\text { the place of } \\
\text { the device } \\
\text { and internet } \\
\text { connection } \\
\text { to access } \\
\text { the } \\
\text { information } \\
\text { or services } \\
\text { [Venkatesh } \\
\text { et al., 2012] }\end{array}$ & $\begin{array}{l}\text { The } \\
\text { services can } \\
\text { be accessed } \\
\text { depend on } \\
\text { the } \\
\text { availability } \\
\text { and the } \\
\text { location. } \\
\text { Often used } \\
\text { web portals, } \\
\text { submit } \\
\text { electronic } \\
\text { forms[Venk } \\
\text { atesh et al., } \\
\text { 2012]. }\end{array}$ & $\begin{array}{l}\text { Minor } \\
\text { limitation, } \\
\text { because } \\
\text { the } \\
\text { technolog } \\
\text { y related } \\
\text { to e- } \\
\text { governme } \\
\text { nt more } \\
\text { compatibl } \\
\text { e to the } \\
\text { infrastruct } \\
\text { ure such } \\
\text { as desktop } \\
\text { computers } \\
\text { [Evans } \\
\text { and Yen, } \\
\text { 2006] }\end{array}$ & $\begin{array}{l}\text { The } \\
\text { coverage } \\
\text { of the } \\
\text { land- } \\
\text { lines are } \\
\text { very } \\
\text { limited } \\
\text { in rural } \\
\text { areas } \\
\text { [TRA } \\
\text { Oman, } \\
\text { 2016] }\end{array}$ \\
\hline
\end{tabular}




\begin{tabular}{|c|c|c|c|c|c|c|c|}
\hline $\begin{array}{l}\text { M- } \\
\text { governme } \\
\text { nt }\end{array}$ & $\begin{array}{l}\text { mobile } \\
\text { phones, } \\
\text { PDAs, } \\
\text { Laptops } \\
\text { and } \\
\text { portable } \\
\text { computer } \\
\text { s[Sareen } \\
\text { and } \\
\text { Chanana, } \\
\text { 2013] }\end{array}$ & $\begin{array}{l}\text { More personal } \\
\text { devices, portable, } \\
\text { more easier to } \\
\text { send information } \\
\text { anytime to } \\
\text { specific } \\
\text { division[Hassan et } \\
\text { al., 2009] }\end{array}$ & $\begin{array}{l}\text { Mobile phones } \\
\text { enable the } \\
\text { services to be } \\
\text { available and } \\
\text { accessible } 24 / 7 \\
\text { hours, the } \\
\text { devices } \\
\text { automatically } \\
\text { shift the mode } \\
\text { between on and } \\
\text { off depend on } \\
\text { the activation by } \\
\text { applications or } \\
\text { information sent } \\
\text { or } \\
\text { received[Hassan } \\
\text { et al., 2009]. }\end{array}$ & $\begin{array}{l}\text { The } \\
\text { accessed } \\
\text { information } \\
\text { and services } \\
\text { are mobile } \\
\text { from } \\
\text { anywhere } \\
\text { [Alssbaihee } \\
\text { n and Love, } \\
\text { 2015] }\end{array}$ & $\begin{array}{l}\text { The } \\
\text { information } \\
\text { and services } \\
\text { can be } \\
\text { accessed } \\
24 / 7 \text { and } \\
\text { with benefit } \\
\text { of accessing } \\
\text { anywhere , } \\
\text { utilize } \\
\text { mobile } \\
\text { applications } \\
\text { to perform } \\
\text { services } \\
\text { [Zefferer, } \\
\text { 2011] }\end{array}$ & $\begin{array}{l}\text { The } \\
\text { design of } \\
\text { the smart } \\
\text { devices in } \\
\text { different } \\
\text { size but } \\
\text { often } \\
\text { small size } \\
\text { with } \\
\text { limited } \\
\text { display } \\
\text { size[Alssb } \\
\text { aiheen } \\
\text { and Love, } \\
\text { 2015] }\end{array}$ & $\begin{array}{l}\text { Most of } \\
\text { the } \\
\text { areas } \\
\text { are } \\
\text { covered } \\
\text { with 3G } \\
\text { and 4G } \\
\text { network } \\
\text { in most } \\
\text { of the } \\
\text { countrie } \\
\text { s } \\
\text { [Nawras, } \\
\text { 2015] }\end{array}$ \\
\hline
\end{tabular}

\section{Transaction classification}

In order to move to m-government, the government agencies should consider the types of transactions that would be included in delivering the services. Zefferer [2011] stresses in his study that there are three types of m-government transactions that have been identified by different research studies:

- Informational transactions: contain messages broadcasting to the citizens and include one way transaction such as sending notifications in case of any events or emergencies. For example in the context of emergency; sending bulk massages to citizens to inform them about the weather forecast [Zefferer, 2011].

Actually this transaction suits egovernment because it based on agency's website. In m-government the objective is to create an interaction between the agency and the citizens, therefore the following transactions can be considered.

- Operational Transactions: this type aim to improve the government agencies' productivity because the operations can be performed and take place at any time and from anywhere. For example; police officer carries with him a mobile device that enables him to interact directly with database to check vehicles or drivers' information in case of Traffic Violations [Zefferer, 2011].

- Transactional services: enable citizens to interact directly with agencies and follow up with their transactions in transparent manner and complete the requested service smoothly [Zefferer, 2011]. For example; Oman ROP allows citizens to check and pay their violations through mobile application.

\section{M-government status in Oman}

Oman is like other developing countries would like to benefit from new technologies, the penetration of mobile and wireless technologies helps Oman in its strategic development process. According to the Telecommunication Regularity Authority website, Oman has been ranked as the $3^{\text {rd }}$ of the Arab countries in terms of mobile penetration and also the $3^{\text {rd }}$ in terms of Internet user penetration [TRA Oman, 2016]. Oman vision is to transform current services into more effective and advanced public service. Therefore, it began to utilize mobile channels to improve the services to its citizens and other stakeholders. There are several services that started in gradual evolution in Oman such as prepaid mobile phone services and SMS which initiated in 
2001 [Nawras, 2015]. Muscat Municipality is the first entity that developed mobile services; an SMS-Parking Services system which enables motorists to pay parking fees via SMS. The education sector also innovates in its provided services and uses SMS to inform higher secondary schools' students about their results by messaging them with a seat number to specific phone number owned by the ministry of education.

\section{M-government to citizen (MG2C): Push and Pull services in Oman}

M-government is inevitable, extending activities to wireless devices and networks will enable to be more proactive in the operations and services by providing realtime and up-to-date information to the officials on the move and by offering citizens a broader selection of choices of interaction. M-government implementations are emerging as one of the additional valued features for the integrated and flexible data communication and exchange mechanism among government units. Al-Shihi et al. [2009] conducted a SWOT analysis on 2009 to identify the status of m-government adoption in Oman. They refer to some government entities as initatives in Push and pull services such as Muscat security Market. It is an example of push service; it sends every 30 minutes an SMS notification to investors to update them on market news, stock, top winners or losers and about active companies. Also Civil Aviation is cooprated with Oman Mobile that allows users to receive messages about weather via their mobile devices. The Ministry of Manpower sends messages to the citizens or clients when there are new tender or job vacancies.

Some other examples of pull services were offered as SMS-service implemented by Muscat Municipality, Royal Oman Police (ROP) and Ministry of Education in Oman, these services were based on prepaid service through Push SMS application that is offered from the service provider. Al-Shihi et al. [2009] revealed that $62 \%$ of the users were using the SMS-services and they recognized that these services allowed them to easily request and reserve services, for example, Muscat Municipality provides a facility to reserve a parking, from any place, and at any time, through their mobile phones, and ROP introduces a service to allow the drivers to request information about their traffic offences. The process starts by sending a message with civil identity number and vehicle number to '3004' where the driver will receive a reply message on the number of traffic offences and amount to be paid.

Al-Shihi et al. [2009] show there is a strong support from government and full mobile coverage. However; there were lower penetration rate by the Internet, incomplete technological infrastructure, unskilled IT staff, low level of knowledge of mgovernment benefits in both government and citizens, slow adoption of electronic technologies in government agencies and lack of IT training

\section{Mobile Applications}

M-government can be introduced by utilizing different tools such as wireless, mobile technology, mobile services and mobile applications. A mobile application is a software product that is specially developed for mobile operating systems configured on handheld devices, such as smart devices [Hoehle and Venkatesh, 2015]. With growth in the number of the users of mobile phones and the increase demand on electronic services, it would be interesting to have a comprehensive look into mobile applications' adoption and its contribution in improving the productivity, performance of agencies' business[Zefferer, 2011].

Janet [2009] claimed that in Tanzania $46 \%$ of the government agencies/departments implemented online services through their websites and most of the services that require online transactions are applied at least level. Janet [2009] also referred to types of services that may reflect on government functions, users and government entities' stakeholders with an account of the 
dimensions of policies, regulations and the society [Janet, 2009]. Shaikh and Karjaluoto [2015] defined mobile apps as products, services or information which are presented by an entity to allow performing transactions such as "financial or non-financial" transactions by utilizing mobile phones, tablets or smart devices. For example; SMS as prepaid services allows the user to book tickets of buses or trains in some countries [Shaikh and Karjaluoto, 2015].

Al-Busaidy and Weerakkody [2009] mentioned in their study that there are some dimensions which constitute the relation between the government, employees and $\mathrm{m}$ government. Also they clarified the factors that should ensure or impact the implementation of mobile services such as availability, security, confidentiality, productivity, assurance, usability, IT skills, users acceptance, ICT infrastructure and information exchange [Al-Busaidy and Weerakkody, 2009].

Mobile services would encourage the involvement of the citizen and motivate them to apply the services through utilizing mobile applications as a channel to submit their suggestions or report their claims. This approach of service involves effective communication between both parties (the agency and the individual), simulating services and following up the process beneficially by the operations of mobile services. It helps to detect if there are any issues in early stage and ensures the ubiquitous accessibility, transparency of procedures and increases the satisfaction of the individual [Olmstead et al., 2009].

Shaikh and Karjaluoto [2015] suggested four approaches to facilitate accessing mobile applications' services as follows:

- Smartphones allow installation of mobile applications, depending on the type of the device's operating system.

- Some mobile applications can be installed in devices that include a specific mobile browser
- Other application can be installed in tablets but is not allowed to be installed in laptops

- Short messaging (SMS) considered as mobile application services that provide notifications on specific events; but this approach does not require Internet connection in contrast to other approaches [Shaikh and Karjaluoto, 2015].

\section{Mobile apps in Oman}

The government agencies in Oman recognize the importance to adopt mobile apps. They focus on broadcasting information to a greater number of their clients and at a shorter time. The information accessibility, transparency, citizen satisfaction become the government agencies' concern and they aim to enhance their provided services and information [e-Oman, 2016]. However, most of the government agencies' mobile applications are informational based applications. The reviewed literature show that there are limited research studies which studied the mobile government adoption in general and specifically in Oman. However in this section the researchers attempted to give an overview about some of the adopted mobile apps in Oman.

\section{Times of Oman: Mobile App for daily news in English}

"Times of Oman" provides a Mobile App that provides daily news in English. The news is published by Muscat Press and Publishing House SAOC which also runs other print media - the daily newspaper "Times of Oman" in English. Through this service, you can get the latest local news, headlines, business and technology news in to your mobile device. This service is free of charge and can be used through smart phones or similar mobile devices. This is a very useful news sourcing service for citizens and residents of Muscat. 


\section{Prayer Times App: The Ministry of Awqaf and Religious Affairs}

It is a Smartphone App used to know the prayer times and provided by the Ministry of Awqaf and Religious Affairs. It includes many services, as well, such as finding Qiblah direction, knowing prayer exact times according to the area where the user is at the time of request. This program, also, provides alarms for every prayer and you can find out the time left for Athan (call for the prayer) of the next prayer. This mobile App provides a service of finding out the nearest masjid for the user according to his/her location at the time of request. It shows a navigation map to that masjid to help finding it in a short time. This navigation system allows adding new masjids to the map. Furthermore, the App has a calendar of the Islamic events during the Hijry year, as well as to the newsletters issued by the Ministry.

This service is free of charge and can be used through Smartphone or similar mobile devices. This is a very useful news sourcing service for citizens and residents of Sultanate of Oman.

\section{Mobile App: Civil Services Employees' Pension Fund}

Mobile App allows pensioners, inheritors and civil services employees to inquire about different kinds of benefits such as pension salaries and calculates their gratuities. It enables the citizens to provide information regarding pension regulations, uses electronic forms which are integrated with the agency's website and allows calculating their benefits based on pension law rules.

\section{Challenges and barriers affecting $M$ - government adoption}

M-government has become a government's strategy that aims to structure government's business, influence positively on organization's cost and productivity. Understanding the factors that may impact the adoption of m-government assists the government to outline an appropriate plan and take the right decisions to avoid any failure or slowness in the implementation [Zukang et al., 2011]. From the point of view of Al-Hadidi and Rezgui [2010], they classified the barriers into two main elements i.e. technical and non-technical [AlHadidi and Rezgui, 2010]. The following section provides an overview of both types in order to achieve the objectives of this research and identify the factors that may affect the adoption of m-government.

\section{Technical factors}

Infrastructure readiness is an important factor that should be considered carefully when planning to move to m-government. AlHadidi and Rezgui [2010] elaborate in their study that wireless network, mobile access devices, software adoption such as mobile applications and integrated systems between government departments contribute gradually in the implementation of $\mathrm{m}$ government speed. Other challenges are to ensure security and maintain privacy such as avoiding publishing any sensitive data and the capability to protect information from any hacking or vulnerability threats [AlHadidi and Rezgui, 2010].

Zukang et al. [2011] investigate in their study that systems' integration is considered as a challenge in the adoption of $\mathrm{m}$ government. Agencies should ensure their systems' integration and sharing information to improve the flexibility of complete information and processes. Scholl et al. [2012] mention that integration will benefit the organization because it helps the agency establish central unit of government entities that are accountable for merging multiple processes, and facilitate sharing information [Scholl et al., 2012].

\section{Non-technical factors}

Most of the people in developing countries when applying for services prefer to interact with government agencies' employees face to face. Sultana and Ahlan [2014] elaborate on 
their study some of the non-technical barriers that may impact the adoption of $\mathrm{m}$ government such as "Culture, trust, language, resistance to change, quality, management support and user expectation" [Sultana and Ahlan, 2014]. The following section highlights some of these barriers:

\section{Ease of use}

Usability of mobile applications is considered as an important factor that measures citizens' satisfaction and encourages them to interact with their agencies. The individual used to request his/her services or access information through browsing on web browser that is running on the client system. The content is displayed in simple presentation and often presented in electronic forms that allow the user to fill in the forms and submit either through the website or print it and manually submit it to the agency [Shaikh and Karjaluoto, 2015].

Olmstead et al. [2009] express that in mgovernment services context, the situation is more complex because of modern smart devices. The hardware resources, limited presentation of the device, screen size of the device, limited capabilities of input and compatibility to integrate with its browser will cause the user to experience difficulty in interacting with the websites. Alssbaiheen and Love [2015] highlight that the navigation system is considered as one of the significant properties for a successful adoption of mobile application. The citizen will be motivated to use the application if they found it easy to access the information and services. An attractive user interface and frequently generating notifications help the users or guide them on the functions of the application and facilitate achieving citizens' needs and their expectations.

\section{Knowledge or awareness}

Al-Hadidi and Rezgui [2010] stated that more than $50 \%$ of the users are Internet users; however, they are not able to benefit from mgovernment due to lack of knowledge about the usage of the mobile government services.

Zukang et al. [2011] list some points that might be taken into consideration when government agencies intend to adopt mobile applications. Good training during the deployment of the mobile apps technologies and readiness of the infrastructure are factors to ensure stability of adopted mobile services. Well educated employees (about benefits of utilizing mobile services) supports the sustainable adoption of mobile apps.

Al-Hadidi and Rezgui [2010] discuss the importance of awareness among both the citizens and government agencies employees. He referred to responsibility that government agencies should take to educate their employees about the benefits of utilizing mobile apps services, to ensure the reliability of the delivered services or information and impact positively on the adoption of mobile apps [Al-Hadidi and Rezgui, 2010].

\section{Trust and Reliability}

Many studies identified trust as a belief on something or someone. Olmedilla et al. [2006] identified trust as "Trust of a party A to a party $B$ for a service $X$ is the measurable belief of A in that B behaves dependably for a specified period within a specified context (in relation to service X)" [Olmedilla et al., 2006]. Colesca [2015] state that the personality of the individual may vary, and will perhaps be influenced by factors which either encourage them to believe, or not. Therefore, trust involves a certain amount of personal weakness caused by the uncertainty about the behaviour of others, which means that the person cannot be sure whether or not they should proceed. This uncertainty may possibly expose them to risk. Therefore, trust 
might be considered as an important factor that affects individual's' behavior towards experimenting any new technology especially if the user faces uncertainty in that technology. For instance; mobile application's interface acts as a focal point between the citizens and agencies, therefore it is considered as an important key to improve trust with user or may be vulnerability in user's reaction toward mobile apps usage. The way of presenting information and services and the degree of accuracy and quality will assist to improve or reduce the person's trust on those services. Citizens' aspects to get meaningful information and services motivate them to complete the online process of applying for the service. If the individuals have confidence in the agencies' services and information this will contribute to the successful adoption of m-government [Colesca, 2015].

\section{Conceptual Framework Theory and Hypotheses}

The technology acceptance and adoption is one of the issues that have been utilized in many such studies. There are various theories that have been developed in this regard such as Unified Theory of Acceptance and Use of Technology [Alhinai et al., 2013]. To achieve the research objectives, the Unified Theory of Acceptance and Use of Technology (UTAUT) model is adopted here as well. UTAUT is a model offered by Venkatesh et al. (2003). UTAUT emerged of many other theories that build upon predicting personality and social influence on the individual's behavior and his/her intention to adopt or resist to use the technology such as Theory of Reasoned Action (TRA),Technology Acceptance Model (TAM), Motivational Model, Theory of Plan Behavior (TPB) and model of Personal Computer Utilization (PCU) [Thomas et al., 2013].

TAM is the famous theoretical model that has been utilized to explore the user's intention to use technologies. TAM has some limitations because it focuses specifically on understanding the user's attitude towards technologies' adoption and excluding other external factors and demographic variables that may affect the adoptions [Shaikh and Karjaluoto, 2015].

UTAUT is a model that builds after studying many previous models such as TAM and other related models; this model joins previous TAM and related models, to create a more helpful model in analyzing the Information Systems (IS) which exist in a complicated IT environment. The motivation of using UTAUT model is its comprehensive and great power of explanation compared to other acceptance and use models. UTAUT encourages the researcher to adopt it in formulating the research framework [Dulle and Minishi-Majanja, 2011].

Dulle and Minishi-Majanja [2011] compared and contrasted between several technologies acceptance models to determine the most capable model that has the ability to provide better understanding of the user's behavior against the acceptance and usage of technologies. Therefore, they proved in their study that UTAUT model has been recognized by several studies and it contributes to producing better explanation about the factors that influence the user's behavior of acceptance and intention to use new technology than other equivalent models.

Alshehri et al. [2012b] highlight that UTAUT model was developed to demonstrate a more comprehensive picture of the acceptance process than other theories which are considered as separate models that had been capable to do. He also confirms success of integrating the key factors used in information system field in one model (UTAUT) from the previous eight previous models: TRA, TPB, TAM, MPCU, MM, SCT, TAM2, and DOI [Alshehri et al., 2012b].

In this study, the original UTAUT model is modified by adding two more constructs that are called from similar literatures (Trust and quality). The new formulated conceptual 
model consists of seven constructs: performance expectancy, effort expectancy, social influence, facilitating conditions, Trust, quality and Behavioral intention and four moderators: Age, Internet experience, Awareness and Gender [Oliveira et al., 2014], note that the original experience moderator in Venkatesh's UTAUT model was changed to Internet experience in this study. The aim of this new construct is to address the effect on the adoption of mobile applications and identify to which extent it influences the public's behavior intention to use this technology. The moderator's age, awareness, gender and Internet experience were considered to have several moderating impacts on the main factors towards the acceptance of mobile apps.

\section{Hypotheses for the constructs (Independent variables)}

Studying these factors leads to formulating the relevant hypotheses that help to predict whether government employees in Oman have the willingness to use mobile applications and investigate their awareness about mobile applications' contribution to improve organizations' work performance. The framework in Figure 1 bellow examined four independent variables (performance expectancy, effort expectancy, social influence and facilitating conditions) that might have an impact on behavioral intention to use mobile applications, together with the moderating factors. The framework shown in Figure 1 is considered the research framework.

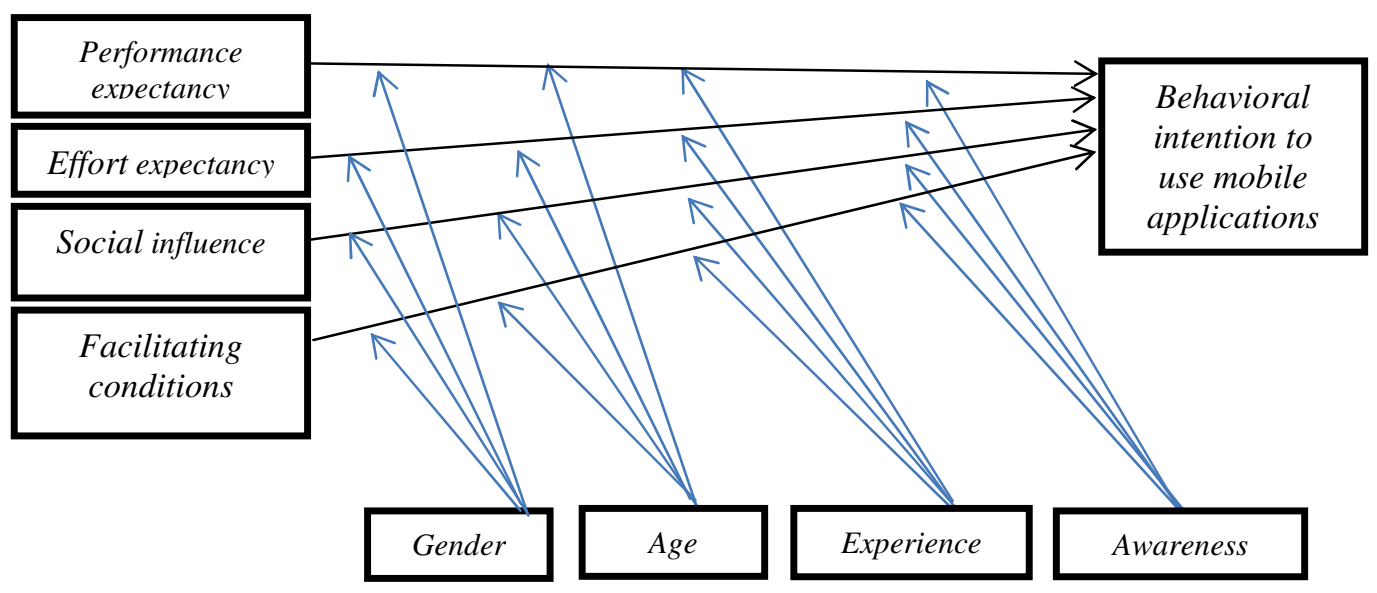

Fig. 1: Research conceptual framework (adopted from [Wu et al., 2012])

\section{- Performance expectancy}

Utilizing mobile government services facilitates the interaction between government agencies and citizens and also benefits both of them in terms of enhancing the services, reducing time and effort of delivering the services and improving the performance of the government agencies' business.
There are some dimensions that should be determined to adopt mobile apps such as maintainability, functionality, availability, usability and responsiveness [Alssbaiheen and Love, 2015]. Performance expectancy is defined as the degree to which individuals believe that adopting a mobile application will benefit them in terms of performing transactions effectively. Referring to the UTAUT model, performance expectancy and expected outcomes in using information 
systems' innovation are related. Therefore, in this study performance expectancy is expected to influence user behavior intention in using mobile application. Individuals are expected to use mobile application if they believe that it will help them improve their job performance [Attuquayefio and Addo, 2014]. Since UTAUT model supports the assumptions that performance expectancy and behavior intention are correlated, this study hypothesized that:

H1: Performance expectancy has a positive influence on behavioral intentions to use mobile application

\section{- Effort expectancy}

Venkatesh et al. [2011] define effort expectancy as the degree of ease related to the usage of information technology. There is a relation between the complicated system and the intention to adopt that system, more complicated system leads to lower acceptance by individuals and lower rate of the adoption. Many theories such as TAM and theory of planned behavior (TPB) include effort expectancy to play role on intention which is interceded by attitude. Individuals are more likely to easily utilize services such as self-service technologies. In contrast, effort expectancy is a bit more difficult to be used with technology.

Therefore, it was suggested that it is important to attach ease of use to several general systems' views about system usage. Users may have specific expectation on the system functionalities then ease of use should reflect several users' aspects and experience. According to the degree of ease of use system will define the users' expectations, will confirm the effort expectancy and influence the user's satisfactions.

Venkatesh et al. [2011] confirm that effort expectancy subsequently influences the satisfaction of individuals and impacts the intention to use the system. Effort expectancy is clearly associated with satisfaction because it indicates the realization of the probable benefits that would be gained from the system. Also it will raise supposed benefits because individuals will modify their opinions in order to be more reliable to the reality.

Effort expectancy is defined as the degree of ease of using mobile application functionalities. This would have significant effect on the implementation of the mobile application which is correlated with the use of the functions. The UTAUT model shows that effort in learning new technology is related to behavioral intention to use the technology. High effort expectancy would result in low intention to use mobile application and vice versa. For instance, if the individual found that a technology is user friendly, his or her intention to use it will increase [Attuquayefio and Addo, 2014]. Since UTAUT model supports the assumptions that effort expectancy and behavior intention are correlated, this study hypothesized that:

H2: Effort expectancy has a positive influence on behavioral intentions to use mobile applications.

\section{- Social influence}

Social influence is the degree to which the employee recognizes how others play significant role in their willingness to whether they should use mobile application or not. This would influence the adoption of mobile application. The UTAUT model indicates how different groups might affect the behavior intention to use. This group might be competitors or colleagues [Attuquayefio and Addo, 2014]. Since UTAUT model supports the assumptions that social influence and behavior intention are correlated, this study hypothesized that:

H3: Social Influence has a positive influence on behavioral intentions to use mobile applications. 


\section{- Facilitating conditions}

Facilitating conditions is the extent to which an individual believes that technical and organizational support, easy accessible sources to digital files, downloading files facility, time response to perform functions, and availability of proper technology to use mobile application are available. The UTAUT model shows that the existence of facilitating conditions contributes to the behavioral intention to use mobile applications. The availability of high support and good infrastructure would have a positive impact on the behavioral intention to use mobile applications[Attuquayefio and Addo, 2014]. Since UTAUT model supports the assumptions that facilitating conditions and behavior intention are correlated, this study hypothesized that:

H4: Facilitating conditions has a positive influence on behavioral intentions to use mobile applications.

\section{Behavioral Intention}

Behavioral intention indicates the degree of individual willingness to follow a behavior and his or her commitment towards this behavior. It also indicates the frequency, duration and the amount of the individual interaction with mobile application. UTAUT model shows that behavior intention affects individual's actions. For instance, high level of intention would increase the probability of taking action and therefore this would affect the usage of mobile application positively [Attuquayefio and Addo, 2014].

\section{Hypotheses for the Moderators}

The study also explores the influence of moderated variables (gender, age, experience and awareness) on the behavior intention to use mobile applications [Dulle and MinishiMajanja, 2011].

- Gender: most studies highlighted that ease of use of the technologies is more attractive and motivates women while men are more motivated by usefulness
[Chiemeke and Evwiekpaefe, 2011]. The effect of Performance expectancy, Effort expectancy, Social influence and Facilitating conditions on Behavioral intention are moderated by "Gender".

- Age: in fact, old age users refer to personality criteria more than early age users, and are more possible to be motivated by ease of use. Chiemeke and Evwiekpaefe [2011] illustrate in their study that age is moderate; almost all the relations within UTAUT and the individual acceptance vary between early age and old age users considering the effect of age [Chiemeke and Evwiekpaefe, 2011]. The effects of Performance expectancy, Effort expectancy, Social influence and Facilitating conditions on Behavioral intention are moderated by "Age".

- Experience: most of the studies illustrated that users who have good experience in using the Internet are more motivated by usefulness; while users who are not interested or inexperienced in using the Internet, they are more expected to be interested in ease of use technologies [Chiemeke and Evwiekpaefe, 2011].

The effects of Performance expectancy, Effort expectancy, Social influence and Facilitating conditions on Behavioral intention are moderated by "Experience".

- Awareness: most of the users who are aware of the usefulness of a technology they explore the benefits of it. These users are more likely to utilize it, while users who are unknowledgeable of the benefits that will be driven to them when they use it may resist to adopt it [Chiemeke and Evwiekpaefe, 2011]. The effect of Performance expectancy, Effort expectancy, Social influence and Facilitating conditions on Behavioral intention are moderated by "Awareness".

Therefore, the research hypotheses including hypotheses for each moderator are illustrated in Table 3 below. 
Table 3: The research hypotheses including hypotheses for each moderator

\begin{tabular}{|c|c|}
\hline \multicolumn{2}{|r|}{ Hypothesis } \\
\hline$H 1$ & $\begin{array}{l}\text { Performance expectancy has a positive influence on behavioral intentions to use mobile } \\
\text { application }\end{array}$ \\
\hline$H 1 a$ & $\begin{array}{l}\text { The effect of performance expectancy on behavioral intention to use mobile application is } \\
\text { moderated by gender }\end{array}$ \\
\hline$H 1 b$ & $\begin{array}{l}\text { The effect of performance expectancy on behavioral intention to use mobile application is } \\
\text { moderated by age. }\end{array}$ \\
\hline$H 1 c$ & $\begin{array}{l}\text { The effect of performance expectancy on behavioral intention to use mobile application is } \\
\text { moderated by experience. }\end{array}$ \\
\hline H1d & $\begin{array}{l}\text { The effect of performance expectancy on behavioral intention to use mobile application is } \\
\text { moderated by awareness. }\end{array}$ \\
\hline$H 2$ & $\begin{array}{l}\text { Effort expectancy has a positive influence on behavioral intentions_to use mobile } \\
\text { applications. }\end{array}$ \\
\hline$H 2 a$ & $\begin{array}{l}\text { The effect of Effort expectancy on behavioral intention to use mobile application is } \\
\text { moderated by gender. }\end{array}$ \\
\hline$H 2 b$ & $\begin{array}{l}\text { The effect of Effort expectancy on behavioral intention to use mobile application is } \\
\text { moderated by age. }\end{array}$ \\
\hline$H 2 c$ & $\begin{array}{l}\text { The effect of Effort expectancy on behavioral intention to use mobile application is } \\
\text { moderated by experience. }\end{array}$ \\
\hline$H 2 d$ & $\begin{array}{l}\text { The effect of Effort expectancy on behavioral intention to use mobile application is } \\
\text { moderated by awareness. }\end{array}$ \\
\hline$H 3$ & Social Influence has a positive influence on behavioral intentions to use mobile applications. \\
\hline$H 3 a$ & $\begin{array}{l}\text { The effect of Social influence on behavioral intention to use mobile application is moderated } \\
\text { by gender }\end{array}$ \\
\hline$H 3 b$ & $\begin{array}{l}\text { The effect of Social influence on behavioral intention to use mobile application is moderated } \\
\text { by age. }\end{array}$ \\
\hline$H 3 c$ & $\begin{array}{l}\text { The effect of Social influence on behavioral intention to use mobile application is moderated } \\
\text { by experience }\end{array}$ \\
\hline$H 3 d$ & $\begin{array}{l}\text { The effect of Social influence on behavioral intention to use mobile application is moderated } \\
\text { by awareness }\end{array}$ \\
\hline$H 4$ & $\begin{array}{l}\text { Facilitating conditions has a positive influence on behavioral intentions to use mobile } \\
\text { applications. }\end{array}$ \\
\hline$H 4 a$ & $\begin{array}{l}\text { The effect of facilitating conditions on behavioral intention to use mobile application is } \\
\text { moderated by gender }\end{array}$ \\
\hline
\end{tabular}

Laila Al-Azizi, Ali H. Al-Badi and Taiba Al-Zrafi (2018), Journal of e-Government Studies and Best Practices, DOI: $10.5171 / 2018.553293$ 


\begin{tabular}{|c|l|}
\hline$H 4 b$ & $\begin{array}{l}\text { The effect of facilitating conditions on behavioral intention to use mobile application is } \\
\text { moderated by age }\end{array}$ \\
\hline$H 4 c$ & $\begin{array}{l}\text { The effect of facilitating conditions on behavioral intention to use mobile application is } \\
\text { moderated by experience }\end{array}$ \\
\hline$H 4 d$ & $\begin{array}{l}\text { The effect of facilitating conditions on behavioral intention to use mobile application is } \\
\text { moderated by awareness }\end{array}$ \\
\hline
\end{tabular}

\section{Research Methodology}

Two approaches were applied in this study. First approach was a comprehensive descriptive literature review including previous studies, in order to gain knowledge and gather more information about the factors that may affect the individual behavior intention to use mobile applications. Then, to examine the correlations between these constructs and the impact on employees' behavioral intention to use mobile applications, an online questionnaire was created. Various employees in government agencies in Oman, who adopted mobile applications, were invited to fill it out.

Therefore, to avoid any issues that may face the survey source such as individuals' interest to answer the questions, a questionnaire was carefully designed to motivate the respondents to provide reliable and accurate data. The questions were clearly developed and made easy to understand by respondents. The sequence of the questions, the content and the format structure of the questions were the major consideration that is involved while formulating the questionnaire. In order to ensure that the sample selection is unbiased, no gender or age limitation was enforced on respondents. In addition to this, the sample was randomly selected within the selected agencies.

The questionnaire designed in bilingual (English and Arabic) in order to survey government agencies' employees. The questionnaire includes closed ended question(s) and consists of two sections. Section (A) presented four normal multiple choices questions that form as moderators. Section (B) consists of independent variables (main constructs) that aim to measure the barriers that may face the individual to use the mobile applications. This section adopted 17-Point Likert-scale types of questions with endpoints of (strongly disagree, disagree, neutral, agree, and strongly agree). This type of questions is used to measure opinions.

On the other hand, Alssbaiheen and Love [2015] illustrated in their study that Likertscale questions have some limitations such as the possibility of acceptance effect because the respondents are more likely to respond with positive answers [Alssbaiheen and Love, 2015]. Therefore, in order to control this issue the design of the questions utilized both negative and positive statements within each scale. In order to ensure that the sample selection is unbiased, no gender or age limitation was enforced on respondents.

\subsection{Target audience}

Rashid [2014] refers in his study to the definition of population on behalf of Polit and Hungler (1999) who identified population as collective of objects, subjects or members that follow a set of characteristics. This study targeted the employees of government agencies who are considered as users of mobile applications and who should have the willingness to adopt government services through mobile applications. The researchers employed a method of probability of random sampling. All features of target population are given an equal opportunity to be selected as a sample.

The following diagram illustrates the research methodology followed in conducting this research. 


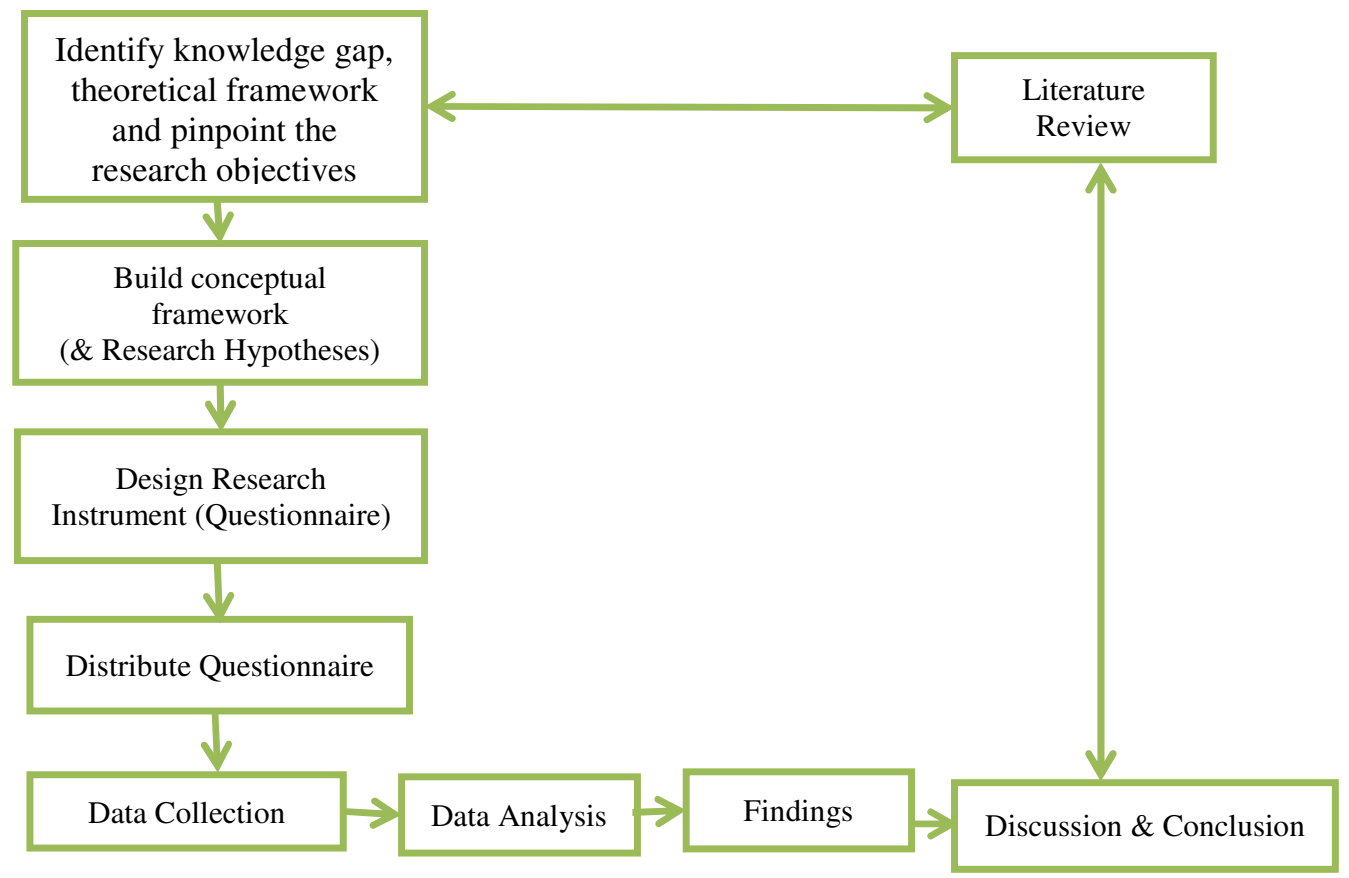

Fig. 2: Research Methodology Diagram

\section{Data analysis}

The collected data were analyzed using a statistical package (i.e. SPSS) that facilitates data analysis process.

\section{Basic data analysis}

The questionnaire was distributed to 180 individuals; however the total number of responses was 135 . Therefore, the response rate is $75 \%$. The reliability of the questionnaire was measured using Cronbach's $\alpha$. Most of the social and information technologies studies used Cronbach's alpha as a measure of reliability. Cronbach's alpha reliability reports the sample value. It is used to measure the internal consistency reliability of a set of items [Bonett and Wright, 2015].

It was found that the overall reliability of the questionnaire is 0.85 , indicating that the questionnaire was developed with good internal consistency. Table 4 shows the reliability of each variable.

As it can be noted, the value of Cronbach $\alpha$ for each variable exceeds 0.7 except Social Influence. Therefore it can be concluded that the responses to those variables are reliable. However, the value corresponding to social influence is low and therefore cautions need to be taken at the stage of hypothesis affected by this variable. 
Table 4: Reliability of each variable

\begin{tabular}{|l|c|}
\hline \multicolumn{1}{|c|}{ Variable } & Cronbach's $\boldsymbol{\alpha}$ \\
\hline Performance Expectancy & 0.76 \\
\hline Effort Expectancy & 0.7 \\
\hline Social Influence & $\mathbf{0 . 2 3}$ \\
\hline Facilitating Conditions & 0.72 \\
\hline Behavioral Intention & 0.79 \\
\hline
\end{tabular}

* Social Influence is less reliable than other variables

Table 5 shows the descriptive statistics of the four moderators where the following can be observed:

- The majority of respondents are female where they made around $74 \%$ of the total.

- The majority of respondents age between 20 to 39 years with approximately $83 \%$ of the total sample.

\section{Table 5: Descriptive analysis of the sample}

\begin{tabular}{|c|c|c|}
\hline Item & Category & Percentage \\
\hline \multirow{3}{*}{ Gender } & Male & $26 \%$ \\
\cline { 2 - 3 } & Female & $74 \%$ \\
\hline \multirow{3}{*}{ Age } & $20-29$ & $41 \%$ \\
\cline { 2 - 3 } & $30-39$ & $42 \%$ \\
\cline { 2 - 3 } & 40 and above & $17 \%$ \\
\hline \multirow{3}{*}{ Experience } & Never used & $4 \%$ \\
\cline { 2 - 3 } & 1 to 6 months & $2 \%$ \\
\cline { 2 - 3 } & 7 to 12 months & $2 \%$ \\
\cline { 2 - 3 } & 1 to 2 years & $21 \%$ \\
\cline { 2 - 3 } & Since Implemented & $70 \%$ \\
\hline \multirow{2}{*}{ Awareness } & Yes & $83 \%$ \\
\cline { 2 - 3 } & No & $17 \%$ \\
\hline
\end{tabular}

\section{Correlation amongst Behavior Intention and other variables}

The correlations among Behavior Intention and other variables are shown on Table 6 where the significance level was set at 95\% significance level. The significant correlations
- Most of the respondents are well experienced in using mobile applications where they started using mobile applications since it was implemented $(70 \%)$.

- Most of the respondents have high awareness (83\%) of mobile applications' usage. are labeled by a star $\left({ }^{*}\right)$ and therefore it can be concluded that there is a significant correlation between Behavior Intention and the following variables: Performance Expectancy, Effort Expectancy and Facilitating Conditions. 
Table 6: Correlation between variables

\begin{tabular}{|c|c|c|c|c|}
\hline Item & $\begin{array}{c}\text { Performanc } \\
\mathbf{e} \\
\text { Expectancy }\end{array}$ & $\begin{array}{c}\text { Social } \\
\text { Influence }\end{array}$ & $\begin{array}{c}\text { Effort } \\
\text { Expectanc } \\
\mathbf{y}\end{array}$ & $\begin{array}{c}\text { Facilitatin } \\
\mathbf{g} \\
\text { Conditions }\end{array}$ \\
\hline $\begin{array}{c}\text { Behavior } \\
\text { Intention }\end{array}$ & $0.492^{*}$ & $\mathbf{0 . 2 8}$ & $0.622^{*}$ & $0.311^{*}$ \\
\hline P-value & 0.000 & $\mathbf{0 . 0 0 1}$ & 0.000 & 0.000 \\
\hline
\end{tabular}

\section{The effects of moderators on each variable}

The following sections investigate the relationships between the independent and dependent variables along with the effect of each of the four moderators. The effects of the moderators on the dependent variable were analyzed using regression analysis.

\section{Gender as a moderator}

Table 7 shows the regression analysis of the dependent variable "Behavior Intention" and the other independent variables. As it can be seen from Table 7, all p-values are less than 0.05 except for Social Influence and therefore it can be assumed as significant. All respondents, whether male or female, pay attention to "Effort expectancy", "Performance Expectancy" and "Facilitating conditions". In other words, "Gender" has an effect on the relationship between "Effort expectancy" and "Behavior intention" as well as the relationship between "Performance Expectancy" and "Behavior intention" and the relationship between "Facilitating conditions" and "Behavior Intention". On the other hand, female respondents stress some relationship between "Behavior Intention" and "Social Influence", while for male respondents there seems to be no relationship between "Behavior Intention" and "Social Influence".

Table 7: Regression analysis of "Behavior Intention" and the other independent variables with gender as a moderator

\begin{tabular}{|c|c|c|c|c|c|}
\hline \multicolumn{2}{|c|}{ Gender } & \multicolumn{2}{c|}{ Male } & \multicolumn{2}{c|}{ Female } \\
\hline \multirow{4}{*}{$\begin{array}{c}\text { Behavioral } \\
\text { intention }\end{array}$} & $\mathbf{R}^{2}$ value & \multicolumn{2}{|c|}{$\mathbf{0 . 5 3 8}$} & \multicolumn{2}{c|}{$\mathbf{0 . 4 8 3}$} \\
\cline { 2 - 6 } & Coefficient & $\boldsymbol{B}$ & $\begin{array}{c}\text { Significance } \\
\text { level }\end{array}$ & $\boldsymbol{\beta}$ & $\begin{array}{c}\text { Significance } \\
\text { level }\end{array}$ \\
\cline { 2 - 6 } & Performance expectancy & 0.581 & $\mathbf{0}$ & 0.479 & $\mathbf{0}$ \\
\cline { 2 - 6 } & Effort expectancy & 0.66 & $\mathbf{0}$ & 0.607 & $\mathbf{0}$ \\
\cline { 2 - 6 } & Social influence & 0.331 & 0.052 & 0.254 & $\mathbf{0 . 0 1 1}$ \\
\cline { 2 - 6 } & Facilitating conditions & 0.471 & $\mathbf{0 . 0 0 4}$ & 0.276 & $\mathbf{0 . 0 0 5}$ \\
\hline
\end{tabular}

\section{Age as a moderator}

As shown in Table 8 the regression of "Behavioral intention" using "Age" as a moderator shows that all age groups pay considerable attention to "Performance Expectancy" and "Effort expectancy".
Respondents over age 30 pay more attention to "Social Influence" than those aged below 30 , meaning that senior people are more concerned about social influence so they are more affected by others' opinion. Respondents aged below 39 emphasize 
"Facilitating conditions" more than those aged over 39.

Table 8: Regression analysis of "Behavior Intention" and the other independent variables with age as a moderator

\begin{tabular}{|c|c|c|c|c|c|c|c|}
\hline \multicolumn{2}{|c|}{ Age Group } & \multicolumn{2}{c|}{$\mathbf{2 0 - 2 9}$} & \multicolumn{2}{c|}{$30-39$} & \multicolumn{2}{c|}{ 40 and above } \\
\hline & $\mathbf{R}^{2}$ value & \multicolumn{2}{|c|}{$\mathbf{0 . 4 1 3}$} & \multicolumn{2}{|c|}{$\mathbf{0 . 6 5 7}$} & \multicolumn{2}{c|}{$\mathbf{0 . 5 4 1}$} \\
\cline { 2 - 8 } & Coefficient & $\boldsymbol{\beta}$ & $\begin{array}{c}\text { Significance } \\
\text { level }\end{array}$ & $\boldsymbol{\beta}$ & $\begin{array}{c}\text { Significance } \\
\text { level }\end{array}$ & $\boldsymbol{\beta}$ & $\begin{array}{c}\text { Significance } \\
\text { level }\end{array}$ \\
\cline { 2 - 8 } $\begin{array}{c}\text { Behavioral } \\
\text { intention }\end{array}$ & $\begin{array}{c}\text { Performance } \\
\text { expectancy }\end{array}$ & 0.505 & $\mathbf{0}$ & 0.504 & $\mathbf{0}$ & 0.454 & $\mathbf{0 . 0 3}$ \\
\cline { 2 - 8 } & $\begin{array}{c}\text { Effort } \\
\text { expectancy }\end{array}$ & 0.48 & $\mathbf{0}$ & 0.779 & $\mathbf{0}$ & 0.569 & $\mathbf{0 . 0 0 5}$ \\
\cline { 2 - 8 } & $\begin{array}{c}\text { Social } \\
\text { influence }\end{array}$ & 0.157 & 0.253 & 0.317 & $\mathbf{0 . 0 1 6}$ & 0.501 & $\mathbf{0 . 0 1 5}$ \\
\cline { 2 - 8 } & $\begin{array}{c}\text { Facilitating } \\
\text { conditions }\end{array}$ & 0.364 & $\mathbf{0 . 0 0 6}$ & 0.332 & $\mathbf{0 . 0 1 2}$ & 0.192 & 0.381 \\
\hline
\end{tabular}

\section{Experience as a moderator}

The number of valid responses from each experience group is shown in Table 5. The responses from respondents with no experience and 1 to 6 months experience were not enough. Therefore, those were collapsed into one group "less than 1 year". As shown in Table 9 the regression of "Behavioral intention" using "Experience" as a moderator shows that all experience groups pay considerable attention to "Effort expectancy". This indicates that the relationship between "Effort expectancy" and "Behavioral intention" will be influenced by users' experience of using mobile applications. Besides, the regression of "Behavior Intention" using "Experience" as a moderator shows that those who used the applications since they were implemented consider "performance expectancy" and "Facilitating conditions" as important. On the other hand, the groups who have less than one year of experience consider "Facilitating conditions" as important and they are also affected by social influence.

Table 9: Regression analysis of "Behavior Intention" and the other independent variables with experience as moderator

\begin{tabular}{|c|c|c|c|c|c|c|c|}
\hline \multicolumn{2}{|c|}{ Experience } & \multicolumn{2}{|c|}{ Less than 1 year } & \multicolumn{2}{|c|}{ 1-2 years } & \multicolumn{2}{|c|}{ Since implemented } \\
\hline \multirow{6}{*}{$\begin{array}{l}\text { Behavior } \\
\text { Intention }\end{array}$} & $R^{2}$ value & & 1 & & 0.586 & & 0.471 \\
\hline & Coefficient & $\boldsymbol{B}$ & $\begin{array}{c}\text { Significance } \\
\text { level }\end{array}$ & $\beta$ & $\begin{array}{c}\text { Significance } \\
\text { level }\end{array}$ & $\beta$ & $\begin{array}{c}\text { Significance } \\
\text { level }\end{array}$ \\
\hline & $\begin{array}{c}\text { Performance } \\
\text { expectancy }\end{array}$ & 0.324 & 0.048 & 0.362 & 0.054 & 0.481 & $\mathbf{0}$ \\
\hline & $\begin{array}{c}\text { Effort } \\
\text { expectancy }\end{array}$ & 0.662 & 0.019 & 0.626 & $\mathbf{0}$ & 0.653 & $\mathbf{0}$ \\
\hline & $\begin{array}{c}\text { Social } \\
\text { influence }\end{array}$ & 0.790 & 0.002 & 0.392 & 0.036 & 0.161 & 0.120 \\
\hline & $\begin{array}{l}\text { Facilitating } \\
\text { conditions }\end{array}$ & 0.728 & 0.007 & 0.230 & 0.229 & 0.249 & 0.015 \\
\hline
\end{tabular}

Laila Al-Azizi, Ali H. Al-Badi and Taiba Al-Zrafi (2018), Journal of e-Government Studies and Best Practices, DOI: $10.5171 / 2018.553293$ 


\section{Awareness as a moderator}

Table 10 shows that all respondents, with or without awareness, pay attention to "Effort expectancy". In other words, "Awareness" has an effect on the relationship between
"Effort expectancy" and "Behavior intention". On the other hand, respondents who have awareness consider "Performance Expectancy", "Social Influence" and "Facilitating Conditions" as important.

Table 10: Regression analysis of "Behavior Intention" and the other independent variables with awareness as a moderator

\begin{tabular}{|c|c|c|c|c|c|}
\hline \multicolumn{2}{|c|}{ Awareness } & \multicolumn{2}{c|}{ Yes } & \multicolumn{2}{c|}{ No } \\
\hline \multirow{4}{*}{$\begin{array}{c}\text { Behavioral } \\
\text { Intention }\end{array}$} & $\mathbf{R}^{2}$ value & \multicolumn{2}{|c|}{$\mathbf{0 . 5 6 2}$} & \multicolumn{2}{|c|}{$\mathbf{0 . 3 2 7}$} \\
\cline { 2 - 6 } & Coefficient & $\beta$ & $\begin{array}{c}\text { Significance } \\
\text { level }\end{array}$ & $\beta$ & $\begin{array}{c}\text { Significance } \\
\text { level }\end{array}$ \\
\cline { 2 - 6 } & Performance expectancy & 0.553 & $\mathbf{0}$ & 0.204 & 0.350 \\
\cline { 2 - 6 } & Effort expectancy & 0.660 & $\mathbf{0}$ & 0.535 & $\mathbf{0 . 0 0 9}$ \\
\cline { 2 - 6 } & Social influence & 0.318 & $\mathbf{0 . 0 0 1}$ & 0.137 & 0.533 \\
\cline { 2 - 6 } & Facilitating conditions & 0.370 & $\mathbf{0}$ & 0.205 & 0.349 \\
\hline
\end{tabular}

\section{Discussion}

UTAUT model was used in this research to examine governmental agencies employees' behavior intention of using mobile application. The main findings are listed below:

It was found from general hypotheses testing those three factors "Performance expectancy", "Effort expectancy", and "Facilitating conditions" have positive influence on "Behavior Intention" to use mobile apps. That is, these hypotheses were accepted. However, Social Influence hypothesis was rejected. The performance expectancy effect positively the individuals' believe on adopting a mobile application and believe that it helps them to improve their job performance which indicates that the government agencies are benefiting from the adoption of mobile application and contribute in enhancing productivity.

In addition to this, four moderators were tested to examine their effect on the relationship between "behavior intention" and the other independent variables. The following was found:
- "Gender" significantly moderates the relationship between "Performance expectancy" and "Behavioral intention"; and the relationship between "effort expectancy" and "Behavioral intention". On the other hand, "Gender" has no effect on the relationship between "Social influence" and "Behavior Intention" and the relationship between "Facilitating conditions" and "Behavior Intention".

- "Age" significantly moderates the relationship between "Performance expectancy" and "Behavioral intention"; and the relationship between "effort expectancy" and "Behavioral intention". On the other hand, "Age" has no effect on the relationship between "Social influence" and "Behavior Intention" and the relationship between "Facilitating conditions" and "Behavior Intention".

- "Experience" significantly moderates the relationship between "effort expectancy" and "Behavioral intention" while "Experience" has no 
effect on the relationship between "Behavior Intention" and the other three factors "Performance Expectancy", "Social influence" and "Facilitating Conditions".

- "Awareness" significantly moderates the relationship between "effort expectancy" and "Behavioral intention" while "Awareness" has no effect on the relationship between "Behavior Intention" and the other three factors "Performance Expectancy", "Social influence" and "Facilitating Conditions".

\section{Conclusion}

The purpose of this study was to explore the factors that may influence the behavioral intention of the government's employees in Oman to use mobile applications and the extent to which they believe that the adoption of mobile applications will contribute in improving productivity and work experience. The findings show that the factors "Performance expectancy", "Effort expectancy and "Facilitating conditions" have relationship with "Behavioral intention". This means that individuals are expected to use mobile applications since they believe that they will help them to improve their job performance. In addition to this, when the individuals found that the technology is userfriendly their intention to use it increases. Moreover, moderators including gender, age, experience, and awareness have a certain moderating effect on some of the variables. For instance, gender affects the relationship of performance expectancy with behavioral intention to use mobile applications as well as the relationship between effort expectancy and behavioral intention to use mobile applications and the relationship between facilitating conditions and behavioral intention to use mobile applications. Similarly, age moderator affects the relationship of performance expectancy with behavioral intention to use mobile applications as well as the relationship between effort expectancy and behavioral intention to use mobile applications.

\section{References}

1. Abdelghaffar, H. and Magdy, Y., (2012), The adoption of mobile government services in developing countries: The case of Egypt, International Journal of Information, vol. 2 (4), pp. 333-341.

2. Al-Busaidy, M. and Weerakkody, V., (2009), E-government diffusion in Oman: a public sector employees' perspective, Transforming Government: People, Process and Policy, vol. 3 (4), pp. 375.

3. Al-Hadidi, A. and Rezgui, Y. (2010), Adoption and diffusion of m-government: Challenges and future directions for research, In Collaborative Networks for a Sustainable WorldSpringer, pp. 88-94.

4. Al-Shihi, H., Naqvi, S. J. and Saqib, A., (2009), M-Government services initiatives in Oman, Issues in informing science and information technology, vol. 6 (2), pp. 817 824.

5. Al Hujran, 0., Aloudat, A. and Altarawneh, I., (2013), Factors influencing citizen adoption of e-government in developing countries: The case of Jordan, International Journal of Technology and Human Interaction (IJTHI), vol. 9 (2), pp. 1-19.

6. Alhinai, Y. S., Albadi, A., Alshihi, H. and AlGharbi, K., (2013), Investigating Determinants of E-banking Adoption by Individuals: Comparing the Impact of System Characteristics and User Traits, International Review of Management and Business Research, vol. 2 (2), pp. 371.

7. Aljawarneh, S., Al-Rousan, T., Maatuk, A. M. and Akour, M., (2012), Usage of data validation techniques in online banking: A perspective and case study, Security Journal, vol. 27 (1), pp. 27.

8. Alshehri, M., Drew, S. and Alfarraj, 0., (2012a), A Comprehensive Analysis of E- 
government services adoption in Saudi Arabia: Obstacles and Challenges, International Journal of Advanced Computer Science and Applications (IJACSA) vol. 2 (3), pp. 1-6.

9. Alshehri, M., Drew, S. and AlGhamdi, R., (2013), Analysis of Citizens Acceptance for Egovernment Services: Applying the UTAUT Model, arXiv preprint arXiv:1304.3157.

10.Alshehri, M., Drew, S., Alhussain, T. and Alghamdi, R. (2012b), The Effects of Website Quality on Adoption of E-Government Service: AnEmpirical Study Applying UTAUT Model Using SEM, In 23rd Australasian Conference On Information SystemsGeelong pp. 3-5 Dec 2012.

11.Alssbaiheen, A. and Love, S., (2015), Exploring the Challenges of $\mathrm{m}$-Government Adoption in Saudi Arabia, Electronic Journal of e-Government, vol. 13 (1).

12.Attuquayefio, S. and Addo, H., (2014), Review of studies with UTAUT as conceptual framework, European Scientific Journal, vol. $10(8)$.

13.Biel, B., Grill, T. and Gruhn, V., (2010), Exploring the benefits of the combination of a software architecture analysis and a usability evaluation of a mobile application, Journal of Systems and Software, vol. 83 (11), pp. 20312044.

14.Bonett, D. G. and Wright, T. A., (2015), Cronbach's alpha reliability: Interval estimation, hypothesis testing, and sample size planning, Journal of Organizational Behavior, vol. 36 (1), pp. 3-15.

15.Chiemeke, S. and Evwiekpaefe, A., (2011), A conceptual framework of a modified unified theory of acceptance and use of technology (UTAUT) Model with Nigerian factors in E-commerce adoption, Educational Research, vol. 2 (12), pp. 1719-1726.
16.Colesca, S. E., (2015), Understanding Trust in e-Government, Engineering Economics, vol. 63 (4), pp. 7-15.

17.Dulle, F. W. and Minishi-Majanja, M. K., (2011), The suitability of the Unified Theory of Acceptance and Use of Technology (UTAUT) model in open access adoption studies, Information Development, vol. 27 (1), pp. 32-45.

18.e-Oman, (2016), Oman eGovernment Services Portal, Accessed on 11-4-2016, Available at: [http://www.oman.om/wps/portal]

19.Evans, D. and Yen, D. C., (2006), EGovernment: Evolving relationship of citizens and government, domestic, and international development, Government Information Quarterly, vol. 23 (2), pp. 207235.

20.Hassan, M., Jaber, T. and Hamdan, Z., (2009), Adaptive mobile-government framework, In the proceeding of Proceedings of the International Conference on Administrative Development: Towards Excellence in Public Sector Performance,

21.Hoehle, H. and Venkatesh, V., (2015), Mobile application usability: conceptualization and instrument development, Mis Quarterly, vol. 39 (2), pp. 435-472.

22.ITA, (2016), Information Technology Authority Accessed on 10-4-2016, Available at:

[http://www.ita.gov.om/ITAPortal/eService s/Popular_Projects.aspx?NID=109]

23.Janet, K., (2009), Determining Types of Services and Targeted Users of Emerging EGovernment Strategies: The Case of Tanzania, International Journal of Electronic Government Research (IJEGR), vol. 5 (2), pp. 16-36.

24.Kailasam, R., (2010), m-Governance... Leveraging Mobile Technology to extend the 
reach of e-Governance, In the proceeding of Proceedings of the TRAI conference on Mobile Applications for Inclusive Growth and Sustainable Development,

25.Kushchu, I. and Kuscu, H., (2003), From Egovernment to M-government: Facing the Inevitable, In the proceeding of the 3rd European Conference on e-Government, 253260

26.Li, M.-H. and Feeney, M. K., (2014), Adoption of electronic technologies in local US governments: Distinguishing between eservices and communication technologies, The American Review of Public Administration, vol. 44 (1), pp. 75-91.

27.Lofstedt, U., (2012), E-governmentassesment of current research and some proposals for future directions, International journal of public information systems, vol. 1 (1).

28. McLandress, K., (2013), Mobile Site vs Native App: Pros and Cons, Accessed on 12/11/2015, Available at: [http://blog.appsbuilder.com/mobile-site-vs-native-apps/]

29.Murugesan, S., (2013), Mobile Apps in Africa, IT Professional, vol. 15 (5), pp. 8-11.

30.Nawras, (2015), The name Nawras had a unique Omani identity, BusinessToday, vol. Jan2015 (194), pp. 19.

31. Norris, D. F. and Reddick, C. G., (2013), Local e-government in the United States: Transformation or incremental change?, Public Administration Review, vol. 73 (1), pp. 165-175.

32.Oliveira, T., Faria, M., Thomas, M. A. and Popovič, A., (2014), Extending the understanding of mobile banking adoption: When UTAUT meets TTF and ITM, International Journal of Information Management, vol. 34 (5), pp. 689-703.

33. Olmedilla, D., Rana, O. F., Matthews, B. and Nejdl, W., (2006), Security and trust issues in semantic grids, In the proceeding of Dagstuhl Seminar Proceedings,

34. Olmstead, P. M., Peinel, G., Tilsner, D., Abramowicz, W., Bassara, A., Filipowska, A., Wiśniewski, M. and Žebrowski, P., (2009), Usability Driven Open Platform for Mobile Government, USE-ME.GOV

35.Payne, J., (2013), Secure Mobile Application Development, IT Professional, vol. 15 (3), pp. 6-9.

36.Rashid, M. A. (2014), Adoption of $m$ government services in the ministry of interior and coordination of national government, a $\mathrm{PhD}$ thesis at College of Humanities and Social Sciences (CHSS), University of Nairobi. 37.Sareen, M. and Chanana, L., (2013), Exploring factors affecting use of mobile government services in India, Problems and Perspectives in Management, vol. 11 (4), pp. 86-93.

38.Scholl, H. J., Kubicek, H., Cimander, R. and Klischewski, R., (2012), Process integration, information sharing, and system interoperation in government: A comparative case analysis, Government Information Quarterly, vol. 29 (3), pp. 313-323.

39.Shaikh, A. A. and Karjaluoto, H., (2015), Mobile banking adoption: A literature review, Telematics and Informatics, vol. 32 (1), pp. 129-142.

40.Siddique, W. and Khan, M. N. A., (2015), A Framework to Instigate Good Governance through ICT.

41.Sultana, M. R. and Ahlan, A. R., (2014), Understanding citizen's intention to use mobile government services in Bangladesh: role of perceived good governance and less corruption.

42. Thomas, T. D., Singh, L. and Gaffar, K., (2013), The utility of the UTAUT model in explaining mobile learning adoption in higher education in Guyana, International Journal of Education and Development using 
Information and Communication Technology, vol. 9 (3), pp. 71-87.

43.TRA, (2013), Guidlines in Mobile Government Telecommunications Regulatory Authority (TRA) UAE, vol. 1.

44.TRA Oman, (2016), Achievements in the past decade, Accessed on 29-5-2016, Available at:

[https://www.tra.gov.om/market/info/thecurrent-scene]

45.United Nations (2014), Government Survey 2014: E-government for the Future We Want, United Nations Department of economic and social affairs

46.Venkatesh, V., Chan, F. K. and Thong, J. Y., (2012), Designing e-government services: Key service attributes and citizens' preference structures, Journal of Operations Management, vol. 30 (1), pp. 116-133.

47.Venkatesh, V., Thong, J. Y., Chan, F. K., Hu, P. J. H. and Brown, S. A., (2011), Extending the two-stage information systems continuance model: Incorporating UTAUT predictors and the role of context, Information Systems Journal, vol. 21 (6), pp. 527-555.

48.Wu, M.-Y., Yu, P.-Y. and Weng, Y.-C., (2012), A Study on User Behavior for I Pass by UTAUT: Using Taiwan's MRT as an Example, Asia Pacific Management Review, vol. 17 (1), pp. 92-111.

49.Zefferer, T. (2011), Mobile government: egovernment for Mobile societies. stocktaking of current Trends and initiatives, (Ed, Austria, S. I. T. C.) Secure Information Technology Center - Austria, Austria.

50.Zukang, S., Touré, H. and Gurria, A., (2011), M-government: Mobile technologies for responsive government and connected societies, OECD/International Telecommunication Union, M-Government: Mobile Technologies for Responsive Governments and Connected Societies, OECD Publications, pp. 25-50. 